\title{
The Oxalate, Tannin, Crude Fiber, and Crude Protein Composition of Young Plants of Some Atriplex Species
}

\section{A.M. DAVIS}

\section{Abstract}

Oxalate, tannin, crude fiber, and crude protein contents were determined in 11 introduced Atriplex species and four species native to western North America that might be browsed by wildlife and livestock. Atriplex species of foreign origin resembled domestic species in content of oxalate, tannins, crude fiber, and crude protein, with averages and range similar to those of $A$. canescens. These foreign species could fit into a range ecosystem to improve the quality and quantity of different browse species.

Atriplex (saltbush) occurs throughout the semiarid regions in the western United States, the Middle East, Australia, Africa, and Siberia. In the western United States the genus Atriplex is represented by annuals, herbaceous perennials, and woody shrubs. Jepson (1951) listed 29 species present in California. Tidestrom (1925) noted 30 species in the Utah and Nevada region, while Rydberg (1954) found 37 species in the Rocky Mountains and the adjacent plains. Some of the important browse species in the western United States are fourwing saltbush, Atriplex canescens (Pursh.) Nutt.; Nuttall saltbush, $A$. nuttallii S. Wats.; shadscale, $A$. confertifolia (Torr. \& Frem.) S. Wats.; and allscale saltbush, $A$. polycarpa $\mathrm{S}$. Wats.

Fourwing saltbush is currently being reseeded on rangelands and reclaimed surface-mined lands. Some workers feel revegetation should be limited to native species. This report compares some forage-quality factors of even-aged samples of native and introduced Atriplex species held by the Western Regional Plant Introduction Station, Pullman, Washington, that may contribute to the browse needs of wildlife and livestock.

\section{Materials and Methods}

Atriplex species received by the Western Regional Plant Introduction Station were established in the field in April 1970. The Atriplex species listed in Table 1 were grown in the greenhouse for 6 weeks. About 5 to $10 \mathrm{~cm}$ of stem growth was trimmed from the seedlings before transplanting them at Central Ferry, Washington. Ambient temperatures at this location seldom drop below $18^{\circ} \mathrm{C}$ in the winter but frequently exceed $38^{\circ} \mathrm{C}$ in the summer. The soil was classified as Spofford, a member of the fine-silty, mixed, mesic Natrixerolls. This soil has good internal and external drainage and is nearly neutral ( $\mathrm{pH} 6.7)$. The planting received $56 \mathrm{~kg} / \mathrm{ha}$ of $\mathrm{N}$ annually as $\mathrm{NH}_{4} \mathrm{NO}_{3}$ and was irrigated, as needed, with a sprinkler system.

The trimmings from the 6-week-old greenhouse-grown seedlings were used to determine oxalate levels in juvenile tissue. During the last week of August and the first week in December, triplicate

\footnotetext{
Author is research agronomist, Western Regional Plant Introduction Station, Washington State University, Pullman, Washington 99164.

This report is a contribution of the Western Regional Plant Introduction Station, Agricultural Research, Science and Education Administration, U.S. Department of Agriculture, in cooperation with the College of Agriculture Research Center, Washingt on State University, Pullman 99164 . Scientific paper No. 5481 of the latter. Manuscript received March 3, 1980.
}

samples of 10 twigs ( $15-25 \mathrm{~cm}$ long) from each of 10 field-grown plants (30 twigs per plant) from each accession were bulked and dried at $26^{\circ} \mathrm{C}$ in a forced-d raft oven. These samples were ground to 20-mesh fineness in a Wiley mill ${ }^{1}$ and stored at room temperature in Kraft paper envelopes. Samples were analyzed between December and April following harvest. The nursery was retained for 4 years for observation of winterhardiness and seed production. Since all plants were needed for seed production, no tissue analyses were made beyond the 1 st year's growth.

Spofford soil contains no detectable selenium. Davis (1972) showed that many Atriplex species will accumulate selenium if grown on seleniferous soil. Of the 14 species studied, $A$. canescens accumulated $204 \mathrm{ppm}$ when growing on soil with $18 \mathrm{ppm}$ selenium, while $A$. lentiformis growing in the same soil contained only $7 \mathrm{ppm}$. Other species varied between these extremes.

Oxalates were determined by the method of Dye (1956), and tannins, by the colorimetric method of Burns (1963). Protein and crude fiber were determined by procedures outlined in AOAC (1970).

\section{Results and Discussion}

Concentrations of oxalates, tannins, crude fiber, and crude protein at two stages of growth are presented in Table 1.

Analysis of the 6-week-old greenhouse-grown seedlings showed oxalate levels to be about the same as the toxic level $(8.7 \%)$ reported by Dye (1956). The highest oxalate level (12.6\%) was found in 6-week-old seedlings of A. leptocarpa F. Muell., PI 342565 , from Australia, and the lowest (4.2\%), in the unidentified Atriplex sp., PI 330670, from Argentina, reported to be a seashore type with $\boldsymbol{A}$. atacamensis or $\boldsymbol{A}$. canescens growth characteristics.

Oxalate concentrations of field-grown mature (6-month- and 9-month-old) tissue were below the toxic level and decreased markedly with increasing maturity. The August sampling showed that $A$. atacamensis Phil., PI 330655, and A. lentiformis S. Wats., PI 330661, retained a oxalate level of 3.9\%. By December, oxalate levels in $\boldsymbol{A}$. canescens, PI 346419, and $A$. semibaccata $\mathrm{R}$. Br., PI 299488 , had dropped to only $0.9 \%$.

Data summarized in Table 1 show that young, succulent, rapidly growing tissue is more likely to contain oxalates in toxic amounts than older, maturing tissue. Morton et al. (1959) reported that a healthy mature sheep required the intake of $45 \mathrm{~g}$ of oxalate to develop toxicity. On that basis, if the diet consisted solely of 6-week-old seedlings of $A$. leptocarpa, $360 \mathrm{~g}$ of dry matter containing $12.6 \%$ oxalates would produce toxicity. This is unlikely to occur because other forage species are present in the animal's diet. In August the ingestion of $1,153 \mathrm{~g}$ of $A$. atacamensis or A. lentiformis at $3.9 \%$ oxalates would be required, and in December the ingestion of $1,283 \mathrm{~g}$ of $A$. lentiformis at $3.5 \%$ oxalates would be

Mention of a trademark or proprietary product does not constitute a guarantee or warranty of the product by the USDA and does not imply its approval to the exclusion of other products that may also be suitable. 
required. With all other accessions studied, more than these amounts would be required at the same growth stage.

Donnelly and Anthony (1969) reported that the tannin level required for rejection by the grazing animal is about $20 \mathrm{mg} / \mathrm{g}$ dry matter. None of the accessions approached this level on the dates sampled. Tannin levels were below $6 \mathrm{mg} / \mathrm{g}$ in all of the August sa mples except those from $A$. canescens, PI 330657 and PI 330658; $A$. muelleri Benth., PI 330663; and $A$. nummularia Lindl., PI 308594. In December the highest level was $9.2 \mathrm{mg} / \mathrm{g}$ dry matter in A. canescens, PI 330658. This accession tends towards evergreenness, and retention of higher tannin levels may be associated with this characteristic.

In the majority of the accessions tested, crude fiber increased several-fold from August to December. Maturation of woody tissue coupled with loss of leaves contributed to this increase. Even though a number of accessions remained almost evergreen, crude fiber increased in all accessions. Atriplex nummularia, PI 342566, had the least and Atriplex sp., PI 330671, the greatest increase in crude fiber. The former is nonhardy and was killed by frost before the last sample was taken. The latter is deciduous, and the increase in crude fiber is enhanced by the complete loss of leaves; only leafless twig tips were available for sampling. Some accessions held a large proportion of the leaf mass, while other dropped all leaf tissue.

The mean crude-fiber level of all accessions at the August harvest date $(16.8 \%)$ was less than that of good $\# 2$ alfalfa hay (Miller 1958); the mean for the December harvest (30.9\%) was greater than that of \#2 alfalfa hay. These data show that crude fiber alone should not limit utilization of most of these Atriplex species for browse.
In August crude protein levels varied from $12.8 \%$ in $A$. nummu laria, PI 330664, to $9.6 \%$ in A. canescens var. linearis (S. Wats. Munz., PI 330658, and $A$. canescens, PI 346419. In December thi crude protein content ranged from $5.4 \%$ in $A$. leucoclada var turcomanica (Moq.) Zoh., PI 339807; A. muelleri, PI 330663; anc A. semibaccata, PI 342571 , to $10.5 \%$ in $A$. nummularia, PI 342566 Protein content was fairly uniform in these 1 st-year plants; the coefficients of variation in protein content for the August anc December harvests were $8 \%$ and $21 \%$, respectively (Table 1). Oxal. ate, tannin, and crude fiber content did not exhibit the uniformity of crude protein (Table 1).

Lack of winterhardiness may be a problem with many intro duced accessions. Minimum winter (November through March) temperatures following establishment were below $0^{\circ} \mathrm{C}$ for 42 day: with a low of $-20^{\circ} \mathrm{C}$. The second year had 34 days below $0^{\circ} \mathrm{C}$, with a low of $-15^{\circ} \mathrm{C}$, and in the third year, 83 days were below $0^{\circ} \mathrm{C}$ with a low of $-8^{\circ} \mathrm{C}$. The extended cold periods in the third year killec many other plants that were considered to be fully winterhardy Few of the woody species flowered the first year. Observations in succeeding years showed that many of the accessions had jus 1 finished flowering when the first frosts occurred in late October o1 early November. These accessions are useful only in areas with a longer growing season than is present at Central Ferry, Washington. The Range Plant Handbook (USDA, Forest Service, 1937), indicates that the shrubby Atriplex accessions from Australia are nonhardy, as are many of the accessions reported here. Nonhardiness is also displayed by much of the material from Israel. Most accessions of $A$. semibaccata, a vigorous herbaceous mat formet that produces a large quantity of forage, failed to overwinter; only PI 29488 matured seed and produced volunteer seedlings. The

Table 1. Oxalate, tannin, crude fiber, and crude protein concentration of some Atriplex species.

\begin{tabular}{|c|c|c|c|c|c|c|c|c|c|c|c|}
\hline \multirow{3}{*}{$\begin{array}{l}\text { Plant } \\
\text { Introduction } \\
\text { number }\end{array}$} & \multirow{3}{*}{$\begin{array}{l}\text { Atriplex } \\
\text { species }\end{array}$} & \multirow[b]{3}{*}{ Origin } & \multicolumn{3}{|c|}{ Oxalates } & \multirow{2}{*}{\multicolumn{2}{|c|}{ Tannin ${ }^{1}$}} & \multirow{2}{*}{\multicolumn{2}{|c|}{ Crude fiber }} & \multirow{2}{*}{\multicolumn{2}{|c|}{ Crude protein }} \\
\hline & & & \multirow{2}{*}{$\begin{array}{c}6- \\
\text { week-old } \\
\text { seedlings }\end{array}$} & \multirow[b]{2}{*}{ Aug. } & \multirow[b]{2}{*}{ Dec. } & & & & & & \\
\hline & & & & & & Aug. & Dec. & Aug. & Dec. & Aug. & Dec. \\
\hline & & \multicolumn{4}{|c|}{$\%$} & \multicolumn{2}{|c|}{$\mathrm{mg} / \mathrm{g}$} & \multicolumn{2}{|c|}{$\%$} & \multicolumn{2}{|c|}{$\%$} \\
\hline 330655 & atacamensis Phil. & Chile & 6.9 & 3.9 & 2.8 & 5.0 & 7.6 & 13.0 & 33.3 & 11.2 & 6.7 \\
\hline 330656 & breweri S. Wats. & USA & 5.9 & 3.4 & 2.0 & 5.5 & 5.9 & 13.5 & 34.2 & $12.6^{2}$ & 5.5 \\
\hline 330657 & $\begin{array}{l}\text { canescens (Pursh) } \\
\text { Nutt. }\end{array}$ & USA & 9.4 & 3.0 & 1.9 & 6.4 & 7.9 & 14.9 & 31.8 & 11.6 & 7.0 \\
\hline 330658 & $\begin{array}{l}\text { canescens var. } \\
\text { linearis (S. Wats.) } \\
\text { Munz. }\end{array}$ & USA & 7.3 & 3.3 & 2.1 & 6.4 & $9.2^{2}$ & 13.6 & 28.7 & 9.6 & 7.2 \\
\hline 346419 & $\begin{array}{l}\text { canescens (Pursh) } \\
\text { Nutt. }\end{array}$ & USA & 6.4 & 2.3 & 0.9 & 5.0 & 5.9 & 18.2 & 36.2 & 9.6 & 5.6 \\
\hline 330659 & halimus $\mathrm{L}$. & Israel & 7.7 & 3.6 & 2.8 & 5.2 & 5.7 & 20.0 & 32.4 & 11.7 & 7.7 \\
\hline 330661 & lentiformis S. Wats. & USA & 8.3 & 3.9 & $3.5^{2}$ & 5.0 & 3.5 & 13.9 & 19.5 & 11.3 & 6.3 \\
\hline 342565 & leptocarpa F. Muell. & Australia & $12.6^{2}$ & 2.8 & 1.3 & 5.5 & 5.0 & 20.3 & 34.1 & 10.3 & 5.5 \\
\hline 330662 & leucoclada Boiss. & Israel & 6.3 & 2.9 & 2.0 & 5.1 & 6.2 & 15.2 & 34.6 & 10.3 & 5.9 \\
\hline 339807 & $\begin{array}{l}\text { leucoclada var. } \\
\text { turkomanica (Moq.) Zoh. }\end{array}$ & Israel & 9.6 & 2.3 & 1.7 & 5.0 & 5.0 & 20.0 & 35.6 & 11.0 & 5.4 \\
\hline 330663 & muelleri Benth. & Australia & 9.2 & 3.3 & 1.8 & 6.4 & 3.2 & 15.9 & 33.5 & 10.0 & 5.4 \\
\hline 308594 & nummularia Lindl. & Australia & 8.8 & 2.9 & 2.1 & 6.4 & 8.8 & 13.6 & 21.4 & 11.6 & 9.4 \\
\hline 330664 & nummularia Lindl. & Australia & 8.2 & 2.5 & 1.3 & 5.0 & 3.6 & 11.3 & 22.6 & $12.8^{2}$ & 9.5 \\
\hline 342566 & nummularia I indl. & Australia & 4.7 & 3.7 & 1.8 & 4.5 & 4.0 & 14.4 & 15.92 & 12.4 & $10.5^{2}$ \\
\hline 330665 & polycarpa $\mathrm{S}$. Wats. & USA & 6.8 & 2.6 & 1.7 & 5.5 & 4.9 & 17.0 & 31.3 & 10.8 & 8.1 \\
\hline 299488 & semibaccata $\mathbf{R}$. Br. & S. Africa & 8.4 & 1.8 & 0.9 & 4.5 & 5.6 & 19.9 & 36.5 & 10.2 & 6.3 \\
\hline 299489 & semibaccata $\mathrm{R} . \mathrm{Br}$. & S. Africa & 10.8 & 1.9 & 1.2 & $3.0^{2}$ & 5.9 & 19.6 & 25.1 & 11.2 & 7.2 \\
\hline 342571 & semibaccata $\mathbf{R}$. Br. & Australia & 9.0 & 2.5 & 1.1 & 5.9 & 5.0 & 20.8 & 32.5 & 10.2 & 5.4 \\
\hline 342572 & semibaccata $\mathrm{R}$. Br. & Australia & 6.6 & 2.9 & 1.2 & 5.0 & 5.5 & 20.0 & 27.8 & 9.9 & 6.4 \\
\hline 330670 & species & Argentina & 4.2 & 3.2 & 2.0 & 5.5 & 5.5 & 17.2 & 35.4 & 11.0 & 5.6 \\
\hline 330671 & species & Venezuela & 6.6 & 2.9 & 1.1 & 5.9 & 5.2 & 13.2 & $44.8^{2}$ & 10.0 & 5.9 \\
\hline 330697 & verrucifera Bieb. & Iran & 6.2 & 2.8 & 1.5 & 5.9 & 5.5 & 20.3 & 27.0 & 11.4 & 6.5 \\
\hline 330669 & vesicaria Heward & Australia & 5.7 & 2.5 & 1.8 & 5.5 & 4.0 & 20.1 & 36.2 & 11.4 & 7.1 \\
\hline \multirow[t]{3}{*}{342574} & vesicaria Heward & Australia & 6.4 & 2.9 & 1.4 & 4.0 & 4.2 & 17.2 & 31.3 & 11.2 & 6.9 \\
\hline & & Mean & 7.6 & 2.9 & 1.7 & 5.3 & 5.5 & 16.8 & 30.9 & 11.0 & 6.8 \\
\hline & & C.V. & 25 & 19 & 36 & 14 & 28 & 18 & 21 & 8 & 21 \\
\hline
\end{tabular}

'As gallotinic acid

${ }^{2}$ Significantly different at the $5 \%$ level $(\bar{x} \pm 2 \sigma)$ (LeClerg et al. 1962) 
following accessions survived the first winter: $A$. atacamensis, PI 330655; A. breweri S. Wats., PI 330656; A. canescens, PI 330657, PI 346419; $A$. polycarpa S. Wats., PI 330665; Atriplex spp., PI 330670 and PI 330671; and $A$. verrucifera Bieb., PI 330697. Atriplex spp. PI 330670 and 330671 appeared to by hybrids. Neither introduction produced seed, and both winter-killed after 3 years of growth. Only accessions of $A$. canescens, $A$. polycarpa, and $A$. verrucifera were alive in the fourth growing season.

Shrubs are a major forage for livestock and wildlife during much of the year in arid and semiarid rangelands. McKell (1975) showed that shrubs in the intermountain basin furnished adequate digestible protein, phosphorus, and carotene, but were slightly deficient in energy for gestation, which was supplied by the grasses that grew in association with the shrubs. Atriplex species made up a large part of the available browse. The crude protein found in this study was just above the 5\% level reported by McKell (1975) as being adequate for normal gestation. Tannins were well below the level at which animal acceptance is impaired. Crude fiber was within acceptable levels, but accessions like Atriplex sp., PI 330671, with $44.8 \%$ crude fiber, may be marginal. Oxalates were higher than desirable in young plants, but as 1st-year plants matured, the oxalate content decreased to a safe level.

Introduced saltbush species are similar to the North American saltbushes in oxalate, tannin, crude fiber, and crude protein content during the 1 st year's growth. Only during early seedling growth, of native as well as introduced species, was the oxalate level potentially toxic. In late summer and mid-winter oxalates were below the toxic level. Tannins, crude fiber and crude protein, were all at acceptable levels. Introduced browse species are worthy of further research to determine their best adaptation and compati- bility with grass, forb, and shrub species growing on rangelands of North America.

\section{Literature Cited}

Association of Official Agricultural Chemists. 1970. Methods of Analysis, 11 th Ed. Washington, D.C.

Burns, R.E. 1963. Methods of tannin analysis for forage crop evaluation. Georgia Exp. Sta. Tech. Bull. N.S. 32.

Davis, A.M. 1972. Selenium accumulation in a collection of Atriplex species. Agron. J. 64:823-824.

Donnelly, E.D., and W.B. Anthony. 1969. Relationship of tannin, dry matter digestibility and crude protein in Sericea lespedeza. Crop Sci. 9:361-363.

Dye, W.B. 1956. Chemical studies of Halogeton glomeratus. Weeds 4:5559.

Jepson, W.L. 1951. A manual of the flowering plants of California. Univ. California Press. Berkeley.

LeClerg, E.L., W.H. Leonard, and A.G. Clark. 1962. Field plot technique. Burgess Publishing Co., Minneapolis, Minn.

McKell, C.M. 1975. Shrubs-A neglected resource of arid lands. Science 187:803-808.

Miller, D.F. 1958. Composition of cereal grains and forages. Pub. 585. Nat. Academy of Sci. Nat. Res. Council, Washington, D.C.

Morton, H.L., R.H. Haas, and L.C. Erickson. 1959. Oxalate and mineral contents of Halogeton glomeratus. Weeds 7:255-264.

Rydberg, P.A. 1954. Flora of the Rocky Mountains and Adjacent Plains Hafner Publ. Co., New York, N.Y.

Tidestrom, I. 1925. Flora of Utah and Nevada. Contributions from the United States National Herbarium. Vol. 25.

USDA Forest Service. 1937. Range plant handbook. U.S. Government Printing Office. Washington, D.C. 